\title{
THE USE OF COBALT IN SOME COMMON ANAEMIAS OF CHILDHOOD
}

\author{
BY \\ B. L. COLES* \\ From the Department of Paediatrics, Elizabeth Garrett Anderson Hospital \\ (Royal Free Hospital Group), London
}

(RECEIVED FOR PUBLICATION AUgUST 5, 1954)

In view of the unsatisfactory response to iron of certain common anaemias in childhood, it was decided to treat a series of cases with cobalt to find out if this substance would prove a satisfactory substitute for iron in refractory cases. Fifty cases were treated, and all had types of anaemia usually showing a poor response to iron, liver and other haemopoietic agents in common use. There were 31 cases of anaemia associated with infection, 10 were anaemic premature infants and three were cases of rhesus incompatibility after the need for transfusion had passed but which showed a residual anaemia. There was one case of severe physiological anaemia and one which developed anaemia after a Rammstedt's operation, although there was no evidence of gastric haemorrhage. The remaining cases comprised twins with a fairly severe anaemia of unknown aetiology and a case of erythrogenesis imperfecta which is included out of interest in spite of the baby's failure to respond to cobalt.

\section{The Anaemia of Infection}

The anaemia associated with infection is characterized by a normochromic, normocytic blood picture with a colour index of around 1. Microcytosis is occasionally seen but is not accompanied by hypochromia (Saifi and Vaughan, 1944). The anaemia is rarely severe except in cases of longstanding suppuration, but is a considerable problem in childhood as it is resistant to treatment by ordinary haemopoietic agents, favours the development of further infection and may retard convalescence. Evidence of blood regeneration is slight and the reticulocytes are normal or reduced (Kugelmass and Lampe, 1932; Wintrobe, 1951). Saifi and Vaughan (1944), however, found well marked reticulocyte responses in their series of cases with chronic infections, though this was less marked

* A. M. Bird and Mabel Webb Research Scholar, Royal Free Hospital School of Medicine, London. in those with recent acute infections. They found no evidence of increased blood destruction in cases of anaemia associated with infection.

The 31 children with anaemia secondary to infection ranged in age from 2 months to 7 years, with an average of 1 year 5 months. Any cases where the aetiology was in doubt or who were known to be anaemic before infection were excluded from the series. The infections were of all types seen in an acute children's ward, with a predominance of otitis media and bronchopneumonia.

The pre-treatment haemoglobin levels averaged $62.4 \%$ (Haldane $14.8 \mathrm{~g}$. $=100 \%$ ), $9.23 \mathrm{~g}$., and the red cell counts averaged 3.92 million per c.mm. The average colour index before treatment was $0 \cdot 80$.

The red cells before treatment usually appeared normal on the stained film but occasional microcytosis and anisocytosis was seen. This, however, was never a marked feature. All cases had a full blood count before treatment was instigated, haemoglobin and red cells were estimated weekly during the period of treatment and the white cells were counted again at the end of treatment. No cases received iron during the period of cobalt therapy. In the majority of cases, the duration of treatment was three weeks, two cases were treated for six weeks, and three made such satisfactory progress that treatment was stopped after two weeks. Cobalt sulphate was given orally in all cases; the dosage was $25 \mathrm{mg}$. daily in 22 cases, and $20 \mathrm{mg}$. daily in the remaining nine cases.

Results. The results of treatment are expressed in the total rise of haemoglobin and red cells over each week of treatment and are shown in Table 1 . In the two patients in whom treatment was continued for more than three weeks, the figures for the first three weeks only are included in Table 1 . From Table 1 it is apparent that the greatest rise in both red cells and haemoglobin occurred during the first week of treatment. In the second week the 
increases were much less marked but during the third week greater rises were again shown though these did not equal those of the first week. Some of the cases were treated on admission, others, if the blood levels were satisfactory at that time, did not receive cobalt till later in the infection. The average count, at the end of three weeks' treatment, showed a rise of $13.6 \%$ haemoglobin ( 2.01 g.) and 0.83 million red cells. There were no toxic effects in any case.

TABLE 1

RESPONSE OF 31 CHILDREN WITH ANAEMIA SECONDARY TO INFECTION

\begin{tabular}{|c|c|c|c|}
\hline & $\begin{array}{l}\text { Hacmo- } \\
\text { globin }\end{array}$ & $\begin{array}{l}\text { Red Blood } \\
\text { Cells (m.) }\end{array}$ & $\begin{array}{l}\text { Colour } \\
\text { Index }\end{array}$ \\
\hline Average initial count $\ldots$ & $\begin{array}{l}62 \cdot 4 \% \\
9 \cdot 23 \mathrm{~g}\end{array}$ & $3 \cdot 92$ & $0 \cdot 80$ \\
\hline Average final count & $\begin{array}{l}76 \cdot 0 \% \\
11 \cdot 24 \mathrm{~g}\end{array}$ & $4 \cdot 75$ & 0.83 \\
\hline $\begin{array}{r}\text { Average rise over weeks: } \\
\text { (I) } \\
\text { (II) } \\
\text { (III) }\end{array}$ & $\begin{array}{l}7 \cdot 9 \% \\
1.16 \mathrm{~g} \\
3 \cdot 1 \% \\
0.45 \mathrm{~g} \\
4.6 \% \\
0.68 \mathrm{~g}\end{array}$ & $\begin{array}{l}0.48 \\
0 \cdot 19 \\
0 \cdot 24\end{array}$ & \\
\hline
\end{tabular}

$$
\text { Dosage }\left\{\begin{array}{l}
25 \mathrm{mg} . \text { daily in } 22 \text { cases. } \\
20 \mathrm{mg} \text {. daily in } 9 \text { cases. }
\end{array}\right.
$$

The Anaemia of Prematurity

The anaemia of prematurity resembles the anaemia associated with infection in that it is a normochromic normocytic anaemia with little evidence of blood regeneration. After three to four months, iron deficiency plays an increasing part in the pathogenesis of the anaemia and hypochromia and microcytosis become evident. Before this age, however, there is little to suggest that iron deficiency is of importance in the aetiology, and the early anaemia fails to respond to iron. Nine cases of the anaemia of prematurity were treated satisfactorily with cobalt. The nine premature infants had birth weights ranging from $2 \mathrm{lb}$. $1 \mathrm{oz}$. to $4 \mathrm{lb}$., with an average of $3 \mathrm{lb} .3 \mathrm{oz}$. The average age of starting treatment was 10 weeks with a range of 7 weeks to 16 weeks. The maximum degree of anaemia of prematurity occurs from 10 to 14 weeks (Mackay, 1935; Lichtenstein and Nordenson, 1939). These children, therefore, were treated at the height of the anaemia at a time when little response to anything but blood transfusion was to be expected. All cases were treated for three weeks, and the dosage was $20 \mathrm{mg}$. cobalt sulphate daily, given by mouth. No cases received iron during the period of cobalt treatment, the drug was taken well in all cases, and there were no toxic effects.
Results. The results of therapy are shown in Table 2. The cases showed a gradual falling off in the response of both haemoglobin and red cells during the three weeks of treatment as normal blood levels were approached. The results on the whole were more satisfactory in the premature infants than in the cases of infection. This was particularly marked in the rise of haemoglobin and is possibly related to a difference in the mode of action of cobalt in the two series which will be discussed later.

TABLE 2

RESPONSE OF NINE PREMATURE INFANTS

\begin{tabular}{|c|c|c|c|}
\hline & $\begin{array}{c}\text { Haemo- } \\
\text { globin }\end{array}$ & $\begin{array}{l}\text { Red Blood } \\
\text { Cells (m.) }\end{array}$ & $\begin{array}{c}\text { Colour } \\
\text { Index }\end{array}$ \\
\hline Average initial count & $\begin{array}{c}62.0^{\circ} \\
9.17_{\mathrm{g}}\end{array}$ & 2.96 & $1 \cdot 07$ \\
\hline Average final count & $\begin{array}{l}83 \cdot 0^{\circ} \text { 。 } \\
12 \cdot 28 \mathrm{~g} .\end{array}$ & $3 \cdot 81$ & $1 \cdot 11$ \\
\hline $\begin{array}{r}\text { Average rise over weeks: } \\
\text { (I) } \\
\text { (II) } \\
\text { (III) }\end{array}$ & $\begin{array}{l}9 \cdot 3 \% \\
1.37 \mathrm{~g} \\
7.5 \% \\
1.11 \mathrm{~g} \\
5.8 \% \\
0.85 \mathrm{~g}\end{array}$ & $\begin{array}{l}0.48 \\
0.33 \\
0.06\end{array}$ & \\
\hline
\end{tabular}

Dosage: $20 \mathrm{mg}$. daily.

A tenth case, J.T., a premature twin of birth weight $3 \mathrm{lb}$., was seen at the age of $4 \frac{1}{2}$ months when his haemoglobin was $70 \%$ and red blood cells $2 \cdot 54$ million. In view of the high colour index and a normal film, he was started on cobalt, $20 \mathrm{mg}$. daily, and one week later the haemoglobin remained at $70 \%$, though the red cells had risen to 2.8 million. After a further week the haemoglobin had fallen to $64 \%$ and the red blood cells were $3 \cdot 1$ million. At this stage an iron deficiency was obvious and ferrous sulphate, grains $4 \frac{1}{2}$ daily, was introduced in addition to the cobalt. After a further week the haemoglobin was $78 \%$ and red cells 3.62 million, and the cobalt was discontinued. The average colour index before treatment was 1.07 and after treatment $1 \cdot 11$, an indication that the iron supplies of these infants were sufficient to meet the demands of increased haemopoiesis.

\section{Miscellaneous Anaemias}

The eight cases which responded to cobalt are shown in Table 3. Because of the variations in age and type of anaemia, no effort has been made to average the results; the initial counts, final counts and rise over the period of treatment are given. All cases, except J.G., received iron at the same time, but as all had been treated with iron for a minimum of three weeks previously with no response, it is 
TABLE 3

MISCELLANEOUS ANAEMIAS SHOWING RESPONSE TO COBALT

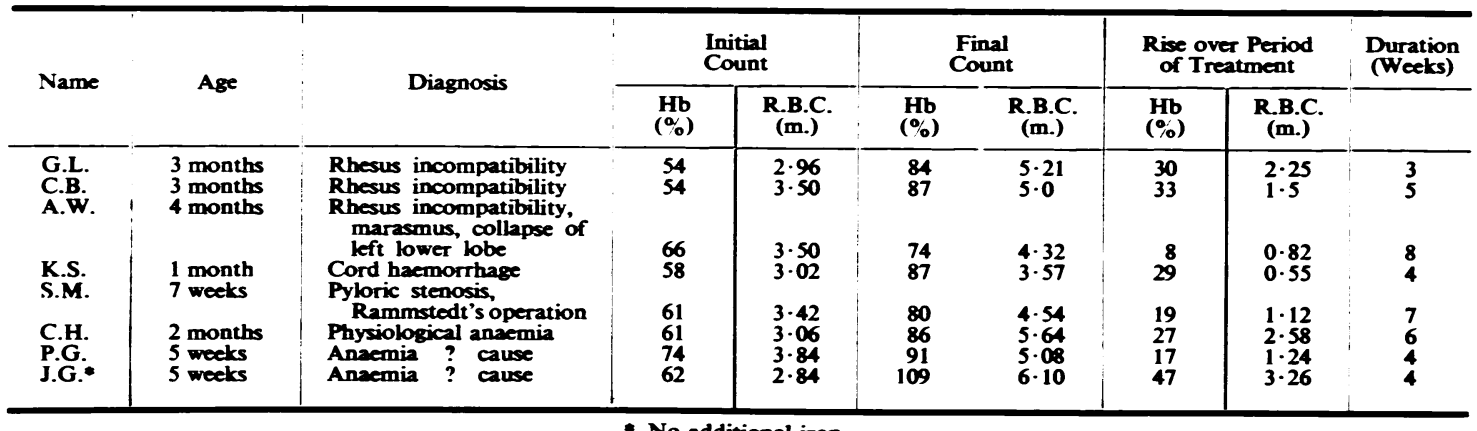

- No additional iron.

unlikely that this was responsible for the satisfactory results. The least satisfactory response occurred in A.W., an infant with erythroblastosis foetalis who, after an exchange transfusion at birth and a later simple transfusion, remained persistently anaemic, marasmic without obvious cause, and just before cobalt treatment was introduced developed a complete collapse of the left lower lobe due to upper respiratory infection. There were thus probably three factors in the production of the anaemia; infection, failure of nutrition, and erythroblastosis, although at 4 months it is unlikely that haemolysis was still active.

The twins, P.G. and J.G., presented an interesting anaemia, the aetiology of which was never established. Born at 38 weeks, with birth weight $7 \mathrm{lb} .15 \mathrm{oz}$. and $5 \mathrm{lb} .1 \mathrm{oz}$, the mother had a severe toxaemia and later developed agranulocytosis for which no cause was found. She was not, however, anaemic during her pregnancy.

The infants, who were never breast-fed owing to the maternal condition, were noted to be pale during the first week of life and at 4 days had haemoglobin of $66 \%$ and $58 \%$ respectively. Iron was given at once, without effect. At the age of 5 weeks, both infants developed mild respiratory infections and were admitted to hospital. No increased haemolysis was detected, the Coombs test was negative, and the bone marrow of both infants was within normal limits. The iron was discontinued in the second twin when cobalt was begun in order to assess if cobalt alone could prove effective; in fact this baby did considerably better than his brother and developed a polycythaemia.

The last case, D.S. (Fig. 1), of hypoplastic anaemia of the type described by Diamond and Blackfan (1938), was included because of the failure to respond to cobalt. This child had had repeated transfusions over a period of years in addition to all the commonly used haemopoietic agents. Marrow studies confirmed the diagnosis with normal cells of the granulocyte series and only $4.0 \%$ total erythroid precursors. The only response obtained in his case was a reticulocytosis of $1.2 \%$ on the second day of treatment. This was not maintained and doubling the dose to $100 \mathrm{mg}$. daily had no

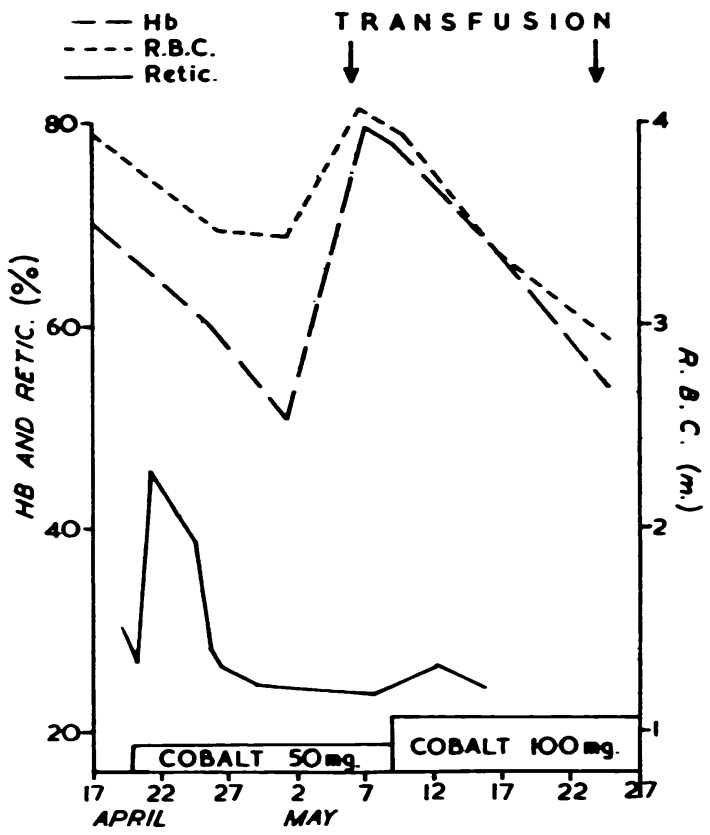

FiG. 1.-A case of erythrogenesis imperfecta.

effect. Diamond and Blackfan (1938) tried iron and cobalt in their four cases without success. Cathie (1950), who suggested the name of erythrogenesis imperfecta for such cases, stated that blood trans- 
fusion was the only satisfactory method of treatment; cobalt was among the drugs tried in his series of five cases. Seaman (1952), however, reported a child kept alive for 10 years with transfusions who developed reticulocytosis and normal erythropoietic tissue in the marrow after treatment with cobaltous chloride. There was no effect following cobalt in a case of congenital hypoplastic anaemia. Encouraging results have been obtained from cobalt therapy in cases of acquired erythrogenic hypoplasia in both adults and children (Seaman and Koler, 1953; Rohn and Bond, 1953) and it is felt that cobalt is worthy of trial in cases of erythrogenesis imperfecta, despite the unsatisfactory results in the case reported here.

\section{Mode of Action of Cobalt}

The mechanism of cobalt in the therapy of anaemia is unknown and further studies were undertaken in some patients in an effort to elucidate this. Twelve cases had marrow punctures before and after cobalt treatment. Six were cases of anaemia with infection and six were premature infants. All these cases responded satisfactorily as far as the peripheral blood was concerned. Nine cases showed a rise in the total erythroid precursors in the marrow, associated with a fall in the myeloid/erythroid ratio. In two cases the levels were approximately the same before and after treatment, and in one case, P.F., the erythroid precursors showed a marked fall after treatment. This was a child of 6 years with miliary tuberculosis who was under treatment with streptomycin and P.A.S. Cobalt in this case was continued for six weeks, and it is possible that the prolonged treatment was responsible for these marrow changes. This would agree with the work of Davis, McCullough and Rigdon (1945) on ducks, which showed a marrow hyperplasia up to the fourteenth day of cobalt treatment, but by the nineteenth day the marrow had become hypoplastic. This was correlated with a decreased proportion of young cells in the peripheral blood though the total counts remained high. It is of interest to note in P.F. that, after an initial rise in both red cells and haemoglobin during the first three weeks of treatment, the haemoglobin remained stationary and the red cells showed a slight but definite fall. After cobalt was discontinued, however, the counts remained satisfactory and there was no evidence of permanent depression of the marrow. The granulocyte series appeared unaffected by this hypoplasia.

Erythroid marrow hyperplasia suggests that one action of cobalt is a direct stimulation of the marrow erythroid tissue. Similar changes in the erythroid tissue after treatment have been noted by Weiss- becker (1950), Wolff (1950), Virdis (1952), Gardner (1953) and Schmöger (1953).

This stimulation is possibly temporary, and if cobalt is continued may give place to a depressant action on the marrow. Table 4 shows the average

TABLE 4

PRE-TREATMENT LEVELS FOR MARROW ERYTHROID SERIES AND PROPORTIONAL RISE OVER INITIAL VALUES AFTER TREATMENT

\begin{tabular}{|c|c|c|c|}
\hline & \multicolumn{3}{|c|}{$\begin{array}{l}\text { Initial Average Levels for } \\
\text { Erythroid Series }\end{array}$} \\
\hline & All & $\begin{array}{l}\text { Premature } \\
\text { Infants }\end{array}$ & Infections \\
\hline $\begin{array}{l}\text { Total erythroid rise (\%) .. } \\
\text { Pro-erythroblast and baso } \\
\text { phil normoblasts }(\%) . .\end{array}$ & $\begin{array}{r}21 \cdot 5 \\
6 \cdot 81\end{array}$ & $\begin{array}{r}20 \cdot 6 \\
6 \cdot 5\end{array}$ & $\begin{array}{l}22 \cdot 4 \\
6 \cdot 94\end{array}$ \\
\hline $\begin{array}{l}\text { blasts } \\
\text { Oxyphilic normoblasts }\end{array}$ & $\begin{array}{r}10 \cdot 47 \\
4 \cdot 31\end{array}$ & $\begin{array}{r}11 \cdot 0 \\
3 \cdot 04\end{array}$ & $\begin{array}{l}9 \cdot 94 \\
5 \cdot 25\end{array}$ \\
\hline
\end{tabular}

\begin{tabular}{|c|c|c|c|}
\hline \multirow{4}{*}{$\begin{array}{l}\text { Total erythroid rise (\%) .. } \\
\text { Proerythroblast and baso- } \\
\text { phil normoblasts (\%) .. } \\
\text { Polychromatic normo- } \\
\text { blasts .. } \\
\text { Oxyphilic normoblasts .. }\end{array}$} & \multicolumn{3}{|c|}{ Proportional rise over initial values } \\
\hline & $16 \cdot 2$ & $22 \cdot 7$ & $10 \cdot 2$ \\
\hline & $15 \cdot 7$ & 6.8 Fall & $22 \cdot 1$ \\
\hline & $\begin{array}{l}19 \cdot 2 \\
25 \cdot 1\end{array}$ & 23.4 & $\begin{array}{c}15 \cdot 4 \\
7 \cdot 1 \text { Fall }\end{array}$ \\
\hline
\end{tabular}

initial levels for the marrow erythroid series. Here the cases are divided into premature infants ando those with infections, and the differences between the two groups of children are most marked in the oxyphilic or late normoblastic series. Table 4 also shows the proportional rise over the initial levels in the various groups. Again, the differences between premature babies and infection cases is most marked at the oxyphilic level. The premature infants showed a rise of $79.1 \%$ at this level, the cases of infection a fall of $7 \cdot 1 \%$ of initial values. The basophilic normoblasts and pro-erythroblasts also showed a marked difference in the reaction of the two groups. The premature infants showed a fall of $6.8 \%$ of the initial value, the cases of infection a rise of $22 \cdot 1 \%$. These figures suggest that cobalt may act differently in the two groups of cases. Stimulation of the late normoblastic series in the premature infants suggests a favourable influence on iron utilization. This would link up with the fact that iron supplies appear adequate in the early anaemia of prematurity and suggests a functional inability to utilize iron for haemopoiesis rather than marrow depression in these infants. This is supported by the work of Lichtenstein and Nordenson (1939) on the bone marrow of premature infants. These authors found no evidence of marrow depression, but rather, an active though immature marrow. It is pointed out by Rohn, Bond and Klotz (1953) that total haemoglobin cannot exceed that represented 
by normochromia of the cells available, so that ultimately the cell count is the limiting factor in the blood picture. As our series of premature babies had a colour index of 1.07 before treatment, it is possible that the initial action of cobalt in all cases is stimulation of red cell production, and in the premature infants the increased utilization of iron is merely secondary to the increased demands of the marrow. After the initial stimulation the action of increased iron utilization may then play the major part in these cases, whereas in the children with infection the direct stimulating action continues to predominate. The premature infants show a rapid rate of growth and presumably their iron demands are in excess of those of children whose blood volume is increasing less quickly and who,

TABLE 5

RETICULOCYTE RESPONSE AFTER ONE TWO AND THREE WEEKS' TREATMENT WITH COBALT

\begin{tabular}{cc|c} 
& \multicolumn{2}{c}{ Average Reticulocyte Response (\%) } \\
\cline { 2 - 3 } Week of & Premature Infants & Infections \\
\hline 1 & 3.4 & 2.3 \\
2 & 2.3 & 1.8 \\
3 & 1.5 & 1.6 \\
\hline
\end{tabular}

once normal blood levels have been reached, have merely to maintain equilibrium. This may also perhaps explain the greater rise in total erythroid precursors seen in the premature infants, $22.7 \%$ over initial figures, compared to a rise of $10.2 \%$ in the cases of infection. The marked increase in the early erythroid cells in the cases with anaemia of infection point to a direct stimulation of the erythroid tissue of the marrow as the main action of the cobalt. This double action of cobalt also seems likely from the work of Kato and Iob (1940). They found marrow hyperplasia of cell elements, particularly of the erythroid series after cobalt administration, and also found less iron storage in the spleen and marrow when cobalt was given with iron than when iron was given alone, thus suggesting that cobalt enhanced iron utilization.

It is realized that no conclusions can be drawn from so few cases but these figures seemed sufficiently striking to suggest a possible dual mechanism for the action of cobalt in anaemia.

These 12 cases also had reticulocyte counts at the end of one, two and three weeks' treatment. The average reticulocyte count before treatment was $0.7 \%$; the counts after treatment are shown in Table 5. The responses obtained were not dramatic, the maximum response being $4 \cdot 7 \%$ at the end of one week, and the premature infants showed rather higher levels than the cases with infection. Robinson, James and Kark (1949) obtained maximum responses in their cases between the sixth and tenth days of treatment, but in no case did the reticulocytes exceed $5 \%$. It is possible that in this series the peak of reticulocytosis was missed, owing to the infrequent examinations, but the findings are in agreement with those of most authors who feel that the reticulocyte responses found after cobalt therapy are not sufficiently marked or consistent to provide a reliable guide to the efficiency of treatment (Rohn et al., 1953; Gardner, 1953; Quilligan, 1954). Some German authors, however (Wolff, 1950; Schmöger, 1953), have reported responses of up to $80 \%$. It is possible that in their series a different technique was used in the estimations.

Examination of peripheral blood films before treatment showed normal red cells in most cases. Occasional hypochromia was present but this was never a marked feature. Polychromatic and nucleated red cells were not seen before treatment. After treatment, however, polychromasia became fairly marked and occasional normoblasts appeared in the films. In the premature infants this was particularly marked. At no time during treatment did hypochromia become marked except in the premature twin, J.T., previously described. This suggested that endogenous iron supplies were adequate in these children. It is felt that if in the course of treatment hypochromia becomes apparent or haemoglobin production lags behind red cell increases, iron should be given in addition.

\section{Summary and Conclusions}

Fifty cases of anaemia in childhood were treated with cobalt and satisfactory results were obtained in all but one case. All had types of anaemia usually resistant to iron therapy.

Marrow studies before and after treatment showed an erythroid hyperplasia in nine of 12 cases.

Reticulocytosis was not marked in the children studied. There were no toxic effects in the dosage used.

The possible mode of action of cobalt in the therapy of anaemia is discussed.

Grateful thanks are due to Dr. Ursula James for her encouragement and criticism and for allowing me to use her cases, to Dr. B. J. Haram for permission to use the blood counts in some of the earlier cases of infection, and to Dr. T. Robson for permission to treat the case of erythrogenesis imperfecta. 


\section{Rerenences}

Cathic, I. A. B. (1950). Archives of Disease in Childhood, 25, 313 Davis, J. E., McCullough, A. W. and Rigdon, R. H. (1945). J. Lab, clin. Med., 30, 327.

Diamond, L. K. and Blackfan, K. D. (1938). Amer. J. Dis. Child. 56, 464.

Gardner, F. H. (1953). J. Lab. clin. Med., 41, 56.

Kato, K. and Iob, V. (1940). Amer. J. clin. Path., 10, 751.

Kugeimass, I. N. and Lampe, M. (1932). Amer. J. Dis. Child. 43, 291.

Lichtenstein, A. and Nordenson, N. G. (1939). Folia haemat., Lpz,

Mackay, H. M. M. (1935). Archives of Disease in Childhood, 10. 195
Quilligan, J. J., Jr. (1954). Tex. St. J. Med., 50, 294.

Robinson, J. C., James, G. W. and Kark, R. M. (1949). New Engl. $J$ Med 240.

Rohn, R. J. and Bond, W. H. (1953). J.-Lancet, 73, 317.

$\overline{\text { Saifi, }} \mathrm{M}$

Saifi, M. F. and Vaughan, J. M. (1944). J. Path. Bact., 56, 189.

Schmöger, R. (1953). Arch. Kinderheilk., 146, 238.

Seaman, A. J. (1952). Amer. J. Med., 13, 99.

and Koler, R. D. (1953). Acta haemat., Basel, 9, 153.

Virdis, S. (1952). Pediatria, Napoli, Wo, no. 5-6, p. 302

Weissbecker, L. (1950). Kobalt als Spurenelement und Pharmakon. Beihefte Med. Monatschr., Stuttgart.

Wintrobe, M. M. (1951). Clinical Haematology, 3rd ed., p. 543. Wintrobe, M. M.

Wolf, H. (1950). Klin. Wschr., 28, 279. 